\title{
Potential of Sverdlovsk Oblast and Yekaterinburg Environmental Sector
}

\author{
Irina Belik $^{1}$, and Natalia Starodubets ${ }^{1 \mathrm{a}}$ \\ ${ }^{1}$ Ural Federal University, 620002, Yekaterinburg, Russia
}

\begin{abstract}
The article discusses the problems associated with introduction of new administrative approaches to solid waste management, as well as the choice of priority directions in the development of the regional waste treatment schemes, which may increase the efficiency of the environmental sector in the city (region) and improve the ecology in general. The authors analyze the factors, which may lead to environmental deterioration and endanger the ecological safety of Yekaterinburg and Sverdlovsk Oblast. They also highlight the priority challenges, one of which is utilization of the biogas produced in the municipal solid waste landfills. In the context of the existing administrative districts, the paper analyzes the results of calculations of biogas production and emissions from the waste incineration plants in Yekaterinburg and Sverdlovsk Oblast. The authors offer an algorithm, which helps to evaluate the reduction of methane emissions to the atmosphere after introduction of a biogas combustion technology. The article also discusses the author's recommendations on how to justify the directions in the development of the regional waste management schemes, which will increase the efficiency of the companies operating in the field of waste management.
\end{abstract}

In compliance with Decree No. 1662-r of the RF Government dated 17.11.2008 one of the main targets for the long-term socio-economic development of the Russian Federation for the period up to 2020 is safety of the country's citizens and society. The transition of the Russian economy from the raw material export pattern to the innovative social-oriented type of development has been chosen as a leading comprehensive and coordinated strategy for achieving this goal. One of indispensable prerequisites for this process is the creation of an innovative and efficient environmental sector, which will meet the needs of the country's growing economy. The adoption of the Russian Environmental Protection Strategy for the period up to 2030 and Federal Law No. 458-FZ dated 12.29.2014 have become the most important steps along this way. In compliance with the last-mentioned law governing waste management sphere, regional schemes should be developed and regional operators should be appointed. It is obvious that realization of this goal may be achieved only after creation of a unified system of control over waste collection, sorting, storage and recycling (Fig. 1).

Regional operators must be appointed on the territory of Sverdlovsk Oblast as well as in other federal subjects of Russia. Their duties will include the development of principle

a Corresponding author: n.v.starodubets@gmail.com 
directions in the field of waste management in the region and major cities. The following areas of focus have been determined for Sverdlovsk Oblast:

1) delivery of wastes to the recycling plants and landfill sites;

2) use of wastes as secondary raw materials;

3) use of biogas as a source of thermal and electric energy.

Figure 1 shows the municipal solid waste management system (MSW), which is the same for all the subjects of the Russian Federation. However, the environmental and economic peculiarities of each region impose their own specifics on the regional schemes and programs (local context).

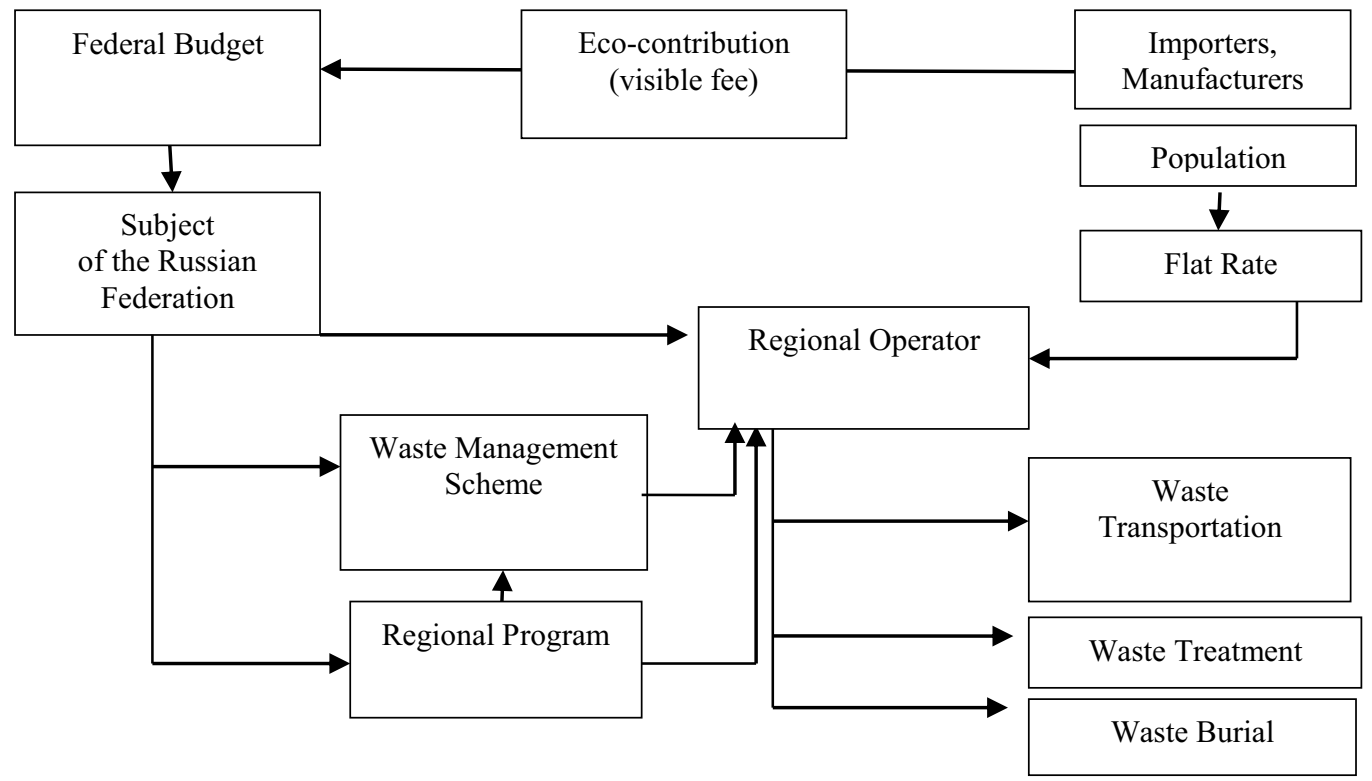

Fig. 1. Waste Management System

In addition, the developers of waste management schemes and regional programs need to create an adequate mechanism for assessment of the environmental effectiveness and economic efficiency of different business options and proposals related to recycling [1]. Consequently, it will be interesting to formulate an algorithm for calculating the volume of emissions from the biogas incineration plants.

Figuratively speaking, the process may be subdivided into five stages. The first stage is to calculate the volume of solid wastes disposed of at landfills. In Yekaterinburg and Sverdlovsk Oblast these calculations were made for each administrative district using the data presented by the Federal Service of State Statistics [2]. On average, per capita waste generation in the region is approximately equal to $400 \mathrm{~kg} / \mathrm{year}$. The population of Sverdlovsk Oblast is 4320.7 thousand people. Table 1 shows the data on the population in the administrative districts.

Table 1. Population of Sverdlovsk Oblast [2]

\begin{tabular}{|c|c|c|c|c|c|c|c|}
\hline \multirow{2}{*}{ Index } & \multirow{2}{*}{ Total } & \multicolumn{4}{|c|}{ Administrative District of Sverdlovsk Oblast } & $\begin{array}{c}\text { Yekate } \\
\text { rinburg } \\
\text { Munici } \\
\text { pal } \\
\text { District }\end{array}$ \\
\cline { 4 - 8 } & & Eastern & Southern & Northern & $\begin{array}{c}\text { Gornoza- } \\
\text { vodskoy }\end{array}$ & Western & 1445,7 \\
\hline Number & 4320,7 & 490,7 & 620,3 & 485,4 & 691,5 & 587,1 & 140.5 \\
\hline
\end{tabular}




\begin{tabular}{|c|c|c|c|c|c|c|c|}
$\begin{array}{c}\text { of residents } \\
\text { as } \\
\text { of 01.01.201 } \\
4, \text { thousand } \\
\text { people (\%) }\end{array}$ & $(100 \%)$ & $(11,4 \%)$ & $(14,3 \%)$ & $(11,2 \%)$ & $(16,0 \%)$ & $(13,6 \%)$ & $\begin{array}{c}(33,5 \% \\
)\end{array}$ \\
\hline $\begin{array}{c}\text { Number } \\
\text { of municipal } \\
\text { ities }\end{array}$ & 94 & 32 & 14 & 15 & 12 & 20 & 1 \\
\hline
\end{tabular}

The annual volume of wastes generated in Yekaterinburg and in each administrative district is calculated on the basis of the data from Table 1 (population size) and Table 2 (waste generation).

Table 2. Waste Generation

\begin{tabular}{|c|c|c|c|c|c|c|c|}
\hline \multirow{2}{*}{ Index } & \multirow{2}{*}{ Total } & \multicolumn{4}{|c|}{ Administrative District of Sverdlovsk Oblast } & $\begin{array}{c}\text { Yekaterin } \\
\text { burg } \\
\text { bunicipal } \\
\text { District }\end{array}$ \\
\cline { 3 - 7 } & Eastern & $\begin{array}{c}\text { Souther } \\
\mathrm{n}\end{array}$ & Northern & $\begin{array}{c}\text { Gornoza- } \\
\text { vodskoy }\end{array}$ & Western & \\
\hline $\begin{array}{c}\text { Municipal } \\
\text { solid waste } \\
\text { generation, } \\
\text { thousand } \\
\text { kg/year }\end{array}$ & 1728280 & 196280 & 248120 & 194160 & 276600 & 234840 & 578280 \\
\hline
\end{tabular}

The second stage is aimed at determining the amount of biogas generated at landfills. For this purpose, it is necessary to analyze the waste composition since it may vary greatly depending on the country, region or population cluster (town, village). The composition of solid wastes is affected by a number of factors, the most important of which are the consumption patterns, the average household income, the type of dwelling (a private house or an apartment building), etc. Thus, EuroStat reports that in the developed countries organic/food/green wastes account for about $55 \%$ of the total waste volume. Other fractions such as paper and paperboard constitute $23 \%$, while plastic and metals are $8 \%$ and $4 \%$ respectively.

The annual volume of biogas generated at landfills under the study was evaluated using "the method of calculating the measurable parameters of pollutant emissions into the atmosphere from the landfills of solid domestic and industrial wastes." Specific biogas yield during the period of its active stable generation in the process of methane fermentation is calculated from equation [3]:

$$
Q=10^{-6}(100-W) R(0,92 F+0,62 C+0,34 P),
$$

where $Q$ is the specific biogas yield during the period of its active generation, $\mathrm{kg} / \mathrm{kg}$ of wastes;

$R$ is the content of organic components in wastes (assumed to be $-55 \%$ );

$F$ is the content of fat-like substances in organic wastes, (assumed to be $-2 \%$ );

$C$ is the content of carbohydrate-like substances in organic wastes (assumed to be $-83 \%$ );

$P$ is the content of protein substances in organic wastes (assumed to be $-15 \%$ );

$W$ is the waste humidity (assumed to be $-47 \%$ ).

Taken into account the aforementioned assumed values, the total biogas content in $1 \mathrm{~kg}$ of wastes is equal to $0.170236 \mathrm{mg} / \mathrm{kg}$.

An annual quantitative yield of biogas per one ton of wastes is calculated by formula [3]:

$$
P_{y}=\left(Q^{*} 10^{3}\right) / t_{c o-d i g} \mathrm{~kg} / t \text { wastes a year }
$$


where $t_{c o-d i g}$ is the period of full scale co-digestion of organic wastes over the period of one year. It is calculated from empirical formula [3]:

$$
t_{\text {co-dig }}=10248 /\left(T_{\text {warm }} *(\text { tav. warm. })^{0,301966}\right.
$$

where: $t_{a v \text { warm }}$ is the mean value of the monthly average air temperatures $\left(\mathrm{t}_{\mathrm{av} \text {. month }}\right)$ around the landfill of municipal and industrial solid wastes (MSW and ISW) during the warm period of the year, $t_{a v \text {. month }}>0$, (assumed to be $+11^{\circ} \mathrm{C}$ );

$T_{\text {warm }}$ is the duration of the annual warm period in the area around the landfill of the municipal and industrial solid wastes, in days (assumed to be 200 days);

10248 and 0.301966 are the specific coefficients, which describe the biothermal decomposition of organic matter.

Taking into account the assumed values, the biogas yield for the year amounted to $6.853423 \mathrm{~kg} / \mathrm{t}$ of waste. On the basis of the data on the annual biogas generation and the population of Sverdlovsk Oblast the authors calculated the volumes of biogas in the landfills of every administrative district (Figure 2).

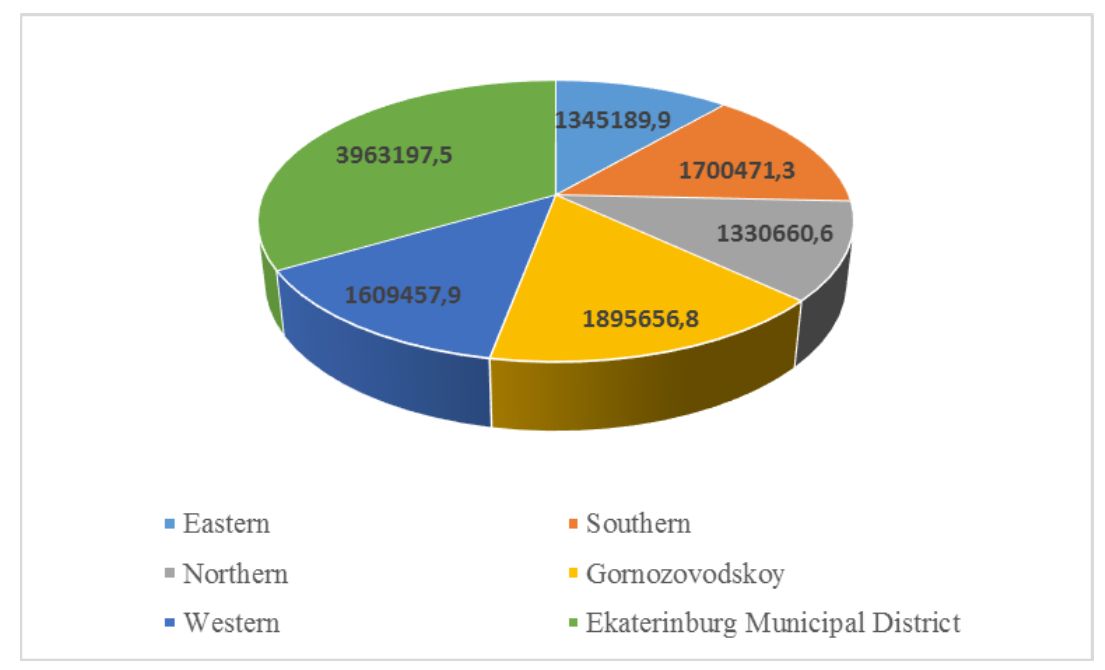

Figure 2. Maximum biogas yield in every administrative district and in Yekaterinburg, $\mathrm{kg} / \mathrm{year}$.

The aim of the third stage is to determine the emissions connected with biogas generation. Biogas is a mixture of methane, carbon dioxide, nitrogen dioxide and oxygen. Depending on the landfill age, biogas composition may vary, that is why the data from Table 3 should be used to calculate the content of each gas [4].

Table 3. Biogas composition under different landfill conditions [4]

\begin{tabular}{|c|c|c|c|c|}
\hline Biogas type* & Methane, $\%$ & $\begin{array}{c}\text { Carbon } \\
\text { dioxide, } \%\end{array}$ & $\begin{array}{c}\text { Oxygen, } \\
\%\end{array}$ & $\begin{array}{c}\text { Nitrogen, } \\
\%\end{array}$ \\
\hline 1 & 55 & 45 & - & - \\
\hline 2 & 40 & 30 & 6 & 24 \\
\hline 3 & 45 & 35 & 1 & 18 \\
\hline 4 & 35 & 30 & 5 & 30 \\
\hline
\end{tabular}

*Note): Type 1 - pure biogas produced under anaerobic conditions, type 2 - the oxygen and nitrogen content in the landfill gas is approximately the same as in the atmospheric air; type 3 - the oxygen from the air over the landfill is used in the microbiological process; type $4-$ a combination of 2 and 3. 
The volume of gaseous pollutants in the landfill gas, emitted into the atmospheric air, is defined using the data from Table 4 (the combined type of gas generation). The calculated volumes of gaseous pollutant emissions into the atmosphere of each administrative district in Sverdlovsk Oblast and Yekaterinburg are shown in Table 4.

Table 4. Volumes of gaseous pollutant emissions connected with different biogas components

\begin{tabular}{|c|c|c|c|c|c|c|c|}
\hline \multirow{2}{*}{ Name } & \multirow{2}{*}{$\begin{array}{c}\text { Total, } \\
\text { t/year }\end{array}$} & Eastern & $\begin{array}{c}\text { Souther } \\
\mathrm{n}\end{array}$ & Northern & $\begin{array}{c}\text { Gornoza } \\
\text { vodskoy }\end{array}$ & Western & $\begin{array}{c}\text { Yekaterin } \\
\text { burg } \\
\text { Municipal } \\
\text { District }\end{array}$ \\
\hline $\begin{array}{c}\text { Methane } \\
\text { (CH4) }\end{array}$ & 4145622 & 470816 & 595165 & 465731 & 663480 & 563310 & 1387119 \\
\hline $\begin{array}{c}\text { Carbon } \\
\text { dioxide } \\
\text { (CO2) }\end{array}$ & 3553390 & 403557 & 510141 & 399198 & 568697 & 482837 & 1188959 \\
\hline $\begin{array}{c}\text { Oxygen } \\
\text { (O2) }\end{array}$ & 592231,7 & 67259 & 85024 & 66533 & 94783 & 80473 & 198160 \\
\hline $\begin{array}{c}\text { Nitrogen } \\
\text { (N2) }\end{array}$ & 3553390 & 403557 & 510141 & 399198 & 568697 & 482837 & 1188959 \\
\hline Total & \multicolumn{7}{|c|}{11844634} \\
\hline
\end{tabular}

However, biogas combustion prevents methane emissions into the atmosphere. Methane has the greatest impact on the greenhouse effect, which is 21 times stronger than that of carbon dioxide. Moreover, methane remains in the atmosphere for an average of 12 years. As we know, methane capture is the best short-term way to prevent global warming. Climate change is manifested in the increased number and strength of different weather events: floods, droughts, heat waves, sharp frosts, strong winds, heavy snowfalls, etc.

The purpose of the fourth stage is to investigate the energy potential of wastes and to offer the options for their use as fuel. The biogas, produced in the landfills of municipal solid wastes (MSW), contains a significant amount of methane, which may be used for energy generation. It should be borne in mind that though, on the one hand, biogas combustion significantly reduces the volume methane emissions, on the other hand, it increases the discharge of harmful exhaust fumes from burning in a CHP plant (Table 5).

Table 5. Greenhouse gas emissions from biogas combustion in CHP [5]

\begin{tabular}{|c|c|c|c|c|}
\hline \multirow{2}{*}{$\begin{array}{c}\text { Biogas } \\
\text { consumption, } \\
\text { thousand } \mathrm{m}^{3} / \text { year }\end{array}$} & \multirow{2}{*}{$\begin{array}{c}\text { Electric power } \\
\text { production, }\end{array}$} & \multicolumn{3}{|c|}{ Greenhouse gas emissions, t/year } \\
\cline { 3 - 5 } & thousand kWh /year & $\mathrm{CO}_{2}$ & $\mathrm{~N}_{2} \mathrm{O}$ & $\mathrm{CH}_{4}$ \\
\hline 345 & 828 & 414,2 & 0,001 & 0,038 \\
\hline 690 & 1656 & 828,3 & 0,002 & 0,076 \\
\hline 1380 & 3311 & 1656,7 & 0,003 & 0,152 \\
\hline 2129 & 4967 & 2556,0 & 0,005 & 0,234 \\
\hline 2759 & 6623 & 3313,3 & 0,067 & 0,364 \\
\hline
\end{tabular}

However, the use of the latest technology available (e.g. Japanese Patent H 05-245339 or a distillation column designed by Russian engineers) offers ways for reduction of carbon dioxide emissions into the atmosphere associated with combustion of biogas.

Stage 5 is used to calculate the amount of individual components (methane, carbon dioxide) in the greenhouse gas emissions from combustion of biogas. The volume of greenhouse gases emitted during burning of 1,000 tons of wastes is determined with 
the use of the interpolation method on the basis of the data presented in Table 5. The volume is calculated by the following formula:

$$
18+((6623-4500) *(34-18)) /(9900-7500)=24290,37 \text { t/year. }
$$

According to the obtained results, the emissions of individual components of the greenhouse gases during combustion of 24290.37 tons of biogas will be as follows: 3313.3 tons of carbon dioxide and 0.364 tons of methane per year. Calculations of biogas volumes generated at landfills indicate that despite the use of combustion technology, there is a significant reduction in emissions of methane into the atmosphere of Sverdlovsk Oblast and Yekaterinburg. Table 6 shows the potential for reduction of harmful emissions after construction of incineration plants, which will burn 24290.37 tons of biogas a year. Such plants are planned to be located in every administrative district of Sverdlovsk Oblast and in Yekaterinburg.

Table 6. Potential for reduction of harmful substances

\begin{tabular}{|c|c|c|c|c|c|c|}
\hline \multirow{2}{*}{ Index } & \multicolumn{5}{|c|}{ Administrative District of Sverdlovsk Oblast } & $\begin{array}{c}\text { Yekaterin } \\
\text { burg } \\
\text { Municipal } \\
\text { District }\end{array}$ \\
\cline { 2 - 7 } & Eastern & Southern & Northern & $\begin{array}{c}\text { Gornozavo } \\
\text { dskoy }\end{array}$ & Western & \\
\hline Methane (CH4) & 412551 & 536900 & 407466 & 605215 & 505045 & 1328854 \\
\hline Decreased by, \% & 12 & 10 & 13 & 9 & 10 & 4 \\
\hline Total & \multicolumn{7}{|c|}{$9,7 \%$} \\
\hline
\end{tabular}

The calculations have shown that the use of biogas generated at landfills is technically possible (since this gas has a high energy potential) and environmentally feasible, because it allows to significantly reduce methane emissions. The results obtained following the reduction of greenhouse gas emissions from combustion of biogas may be applied to the regional waste management schemes, introduced starting from 2015 in accordance with Federal Law No. 458-FZ, as a priority area of the environmental sector development. This is especially important for urban territories, since there is a progressive growth of solid wastes accompanied by the negative tendency in waste generation rate, which exceeds the population growth rate. The technical possibility for burning of biogas to generate heat and electricity leads to a decrease in the volume of emissions into the air and allows to speak about the improved economic efficiency of waste management. The necessary financial resources for the implementation of this technology can be received from the environmental fee (see Fig. 1). However, to make this scheme work, the local government together with the regional operator need to additionally create a secure system of waste collection and transportation on the municipal territories (the city), as well as the conditions for safe waste disposal in the landfills, which should be built in accordance with the regulatory requirements.

\section{References}

1. I. Belik, N. Starodubets, Conference Proceedings 8th Annual Conference of the EuroMed Academy of business, 2468-2472 (2015)

2. Official website of the Federal State Statistics Service of Sverdlovsk Oblast, http://sverdl.gks.ru/ 
3. Method for calculation of measurable parameters of pollutant emissions into the atmosphere from the landfills of solid domestic and industrial wastes, http://www.waste.ru/modules/library/singlefile.php?cid $=1 \& l i d=6$

4. Guidelines for calculation of greenhouse gas emissions from solid waste landfills, http://climatechange.kz/docdowlon/metodik/othod/W1.3.pdf

5. O.V. Masleeva, G.V. Pachurin, Fundamental research, 6-1, 139-144 (2012) 